\title{
Corrigendum: A Nanostructured Lipid System to Improve the Oral Bioavailability of Ruthenium(II) Complexes for the Treatment of Infections Caused by Mycobacterium tuberculosis
}

\section{OPEN ACCESS}

Approved by:

Frontiers Editorial Office,

Frontiers Media SA, Switzerland

*Correspondence:

Patricia B. da Silva

patrbent@yahoo.com.br

Fernando R. Pavan

fernando.pavan@unesp.br;

pavanunesp@gmail.com

Specialty section:

This article was submitted to

Antimicrobials, Resistance and

Chemotherapy,

a section of the journal

Frontiers in Microbiology

Received: 13 May 2019 Accepted: 14 May 2019 Published: 31 May 2019

Citation:

da Silva PB, de Freitas ES, Solcia MC

de Souza PC, da Silva MM,

Batista AA, Eismann CE,

Rolisola AMCM, Menegário AA, Cardoso RF, Chorilli M and Pavan FR

(2019) Corrigendum: A

Nanostructured Lipid System to Improve the Oral Bioavailability of

Ruthenium(II) Complexes for the

Treatment of Infections Caused by

Mycobacterium tuberculosis.

Front. Microbiol. 10:1213.

doi: 10.3389/fmicb.2019.01213
Patricia B. da Silva ${ }^{1 *}$, Eduardo Sinésio de Freitas ${ }^{1}$, Mariana Cristina Solcia ${ }^{1}$, Paula Carolina de Souza ${ }^{1}$, Monize Martins da Silva ${ }^{2}$, Alzir Azevedo Batista ${ }^{2}$, Carlos E. Eismann ${ }^{3}$, Ana Marta C. M. Rolisola ${ }^{3}$, Amauri A. Menegário ${ }^{3}$, Rosilene Fressatti Cardoso ${ }^{4}$, Marlus Chorilli ${ }^{1}$ and Fernando R. Pavan ${ }^{1 *}$

${ }^{1}$ School of Pharmaceutical Sciences, Universidade Estadual Paulista, Araraquara, Brazil, ${ }^{2}$ Department of Chemistry, Universidade Federal de São Carlos, São Carlos, Brazil, ${ }^{3}$ Environmental Studies Center, Universidade Estadual Paulista, Rio Claro, Brazil, ${ }^{4}$ Department of Clinical Analysis and Biomedicine, State University of Maringa, Maringá, Brazil

Keywords: ruthenium(II) complexes, tuberculosis, nanotechnology, oral bioavailability, ICP-MS

\section{A Corrigendum on}

A Nanostructured Lipid System to Improve the Oral Bioavailability of Ruthenium(II) Complexes for the Treatment of Infections Caused by Mycobacterium tuberculosis

by da Silva, P. B., de Freitas, E. S., Solcia, M. C., de Souza, P. C., da Silva, M. M., Batista, A. A., et al. (2018). Front. Microbiol. 9:2930. doi: 10.3389/fmicb.2018.02930

In the original article, we neglected to include the funder "Programa de Apoio ao Desenvolvimento Científico (PADC) of School of Pharmaceutical Sciences/UNESP, Brazil" to all authors.

A correction has therefore been made to the Funding statement:

"This research was funded by grant \#2013/14957-5 and grant \#2013/09265-7 São Paulo Research Foundation (FAPESP) by the Coordination for the Improvement of Higher Education Personnel (CAPES) together with the Post-Doctoral National Program (PNPD), the Programa de Apoio ao Desenvolvimento Científico (PADC) of School of Pharmaceutical Sciences/UNESP, Brazil and the authors thank UNESP for the data of the dissertation (Freitas, 2015).”

The authors apologize for this error and state that this does not change the scientific conclusions of the article in any way. The original article has been updated.

\section{REFERENCES}

Freitas, E. S. (2015). Nanoencapsulação De Compostos De Rutênio, Análise De Sua Atividade Anti-Mycobacterium tuberculosis E Biodisponibilidade Oral. Ph.D. thesis, São Paulo State University, São Paul.

Copyright ( 2019 da Silva, de Freitas, Solcia, de Souza, da Silva, Batista, Eismann, Rolisola, Menegário, Cardoso, Chorilli and Pavan. This is an open-access article distributed under the terms of the Creative Commons Attribution License (CC BY). The use, distribution or reproduction in other forums is permitted, provided the original author(s) and the copyright owner(s) are credited and that the original publication in this journal is cited, in accordance with accepted academic practice. No use, distribution or reproduction is permitted which does not comply with these terms. 